Jerome Dumoulin is an economist in charge of research at CNRS, the Institut Recherche Economique Production Developpement, Grenoble, France.
Correspondence: Dr Xavier Courtois, Centre Hospitalier d'Annecy, 1 avenue de Tresum, BP 333, 74011 Annecy, France

\title{
Quality of primary outpatient services in Dar-es-Salaam: a comparison of government and voluntary providers
}

\author{
NAJMI KANJI, ${ }^{1}$ PETER KILIMA, ${ }^{2}$ NICK LORENZ ${ }^{2,3}$ AND PAUL GARNER ${ }^{1,4}$ \\ 'Department of Public Health and Policy, London School of Hygiene and Tropical Medicine, UK, \\ 'DSM Urban Health Project, City Council, Dar-es-Salaam, ${ }^{3}$ Swiss Tropical Institute, Basel, and \\ 4International Health Division, Liverpool School of Tropical Medicine, UK
}

\begin{abstract}
This study aimed to test whether voluntary agencies provide care of better quality than that provided by government with respect to primary curative outpatient services in Dar-es-Salaam. All non-government primary services were included, and government primary facilities were randomly sampled within the three districts of the city. Details of consultations were recorded and assessed by a panel who classed consultations as adequate, inadequate but serious consequences unlikely, and consultations where deficiencies in the care could have serious consequences. Interpersonal conduct was assessed and exit interviews were conducted. The study found that government registers of non-government 'voluntary' providers actually contained a high proportion of for-profit private providers. Comparisons between facilities showed that care was better overall at voluntary providers, but that there was a high level of indequate care at both government and non-government providers.
\end{abstract}

\section{Introduction}

Voluntary agencies provide a substantial proportion of primary health services in many low income countries. The World Bank recommends that governments form constructive partnerships with the voluntary sector because they provide a better service than services directly run by government.' Yet this assumption has not been widely tested, and is not always the case. ${ }^{2}$

The health service in Tanzania is undergoing reform influenced by the World Bank. Structural adjustment has led to an increased use of voluntary and private health providers, and the introduction of user fees is likely to further increase provider pluralism. ${ }^{3}$ To test the World Bank assumption that the voluntary sector provides better care, we compared outpatient consultations at voluntary and government facilities in Dar-es-Salaam.

\section{Methods}

In Dar-es-Salaam government and voluntary agency primary health care facilities provide a similar range of care. This includes basic outpatient services, and maternal and child health clinics. Clinical staff in outpatient services are mainly medical assistants (paramedics with three years clinical training), doctors and nurses. There are 49 government facilities in the city, excluding hospitals. Previous work had demonstrated socioeconomic differences between the three districts that divide the city (using measures of housing, economic activity, and reported income and expenditure). Therefore, the city was stratified by district and 10 facilities randomly sampled from each for study. ${ }^{4}$

Voluntary providers were initially identified through the City Council's compulsory health provider register. The city medical officer up- 
dated this list by consulting with health staff from each district. This list was checked for completeness by random visits to residential and commercial areas in the three districts. It then became apparent that this final list of 39 officially classified voluntary agency facilities included private for-profit practitioners affiliated to a religious group. It was reported that the favourable tax status of practitioners registered as 'voluntary' was the reason for this. Therefore the ownership of the property and the employment status of staff was checked at each, and services that were autonomous and owned by a private individual were excluded. The remaining 15 voluntary agency facilities were all included in the study. They were run by Catholic (7), Protestant (4) and Muslim (4) groups.

Each sampled facility was visited, staff listed, and throughput recorded. The structure was assessed using a standard method reporting the condition of the building and the presence of basic equipment and drugs. ${ }^{5}$ Trained medical assistants (paramedics with 4 years training) observed the clinical staff for about an hour in the middle of their morning clinics, and took details of 10 consecutive consultations, including history, questions asked, examinations performed, advice given and drugs prescribed on a proforma.
At the end of each field work day, performance of each consultation was assessed by the Assessment Panel, a group of at least three people, comprising the observer, the main researcher who is also a qualified pharmacist (NK), and a clinician (PK). This group used explicit criteria to judge the adequacy of the history and examination. These criteria were based on national treatment schedules, ${ }^{6}$ were specific for each presenting complaint, and had been developed by all the authors of this paper for 30 common conditions. Table 1 gives examples for 3 conditions, showing the minimum and optimum criteria used. If the history and examination reached minimum standards, the panel then went on to judge if the treatment was complete and appropriate given the history, examination and diagnosis made. If this was the case, the consultation was judged as acceptable. Unacceptable consultations were subdivided into three: those where the consequences were unlikely to have serious consequences (for example, a child with a runny nose who is given antibiotics); or those with potentially serious consequences (for example, in a child with cough or fever the clinician must either examine the chest to exclude pneumonia, or prescribe antibiotics, otherwise a potentially serious illness may be missed or go untreated); or finally, those consultations where a treatment is given that goes against established

Tablo 1. Examples of explicit criteria used to classify history and examination adequacy

\begin{tabular}{|c|c|c|c|c|}
\hline \multirow{2}{*}{$\begin{array}{l}\text { Presenting } \\
\text { complaint (s) }\end{array}$} & \multicolumn{2}{|c|}{ History } & \multicolumn{2}{|c|}{ Examination } \\
\hline & minimum & optimum & minimum & optimum \\
\hline Body pain & $\begin{array}{l}\text { duration; } \\
\text { fever }\end{array}$ & $\begin{array}{l}\text { associated } \\
\text { symptoms (x1) }\end{array}$ & temperature & $\begin{array}{l}\text { temperature } \\
\text { check chest OR } \\
\text { abdomen }\end{array}$ \\
\hline $\begin{array}{l}\text { Cough and fever; or } \\
\text { cough and chest pain }\end{array}$ & $\begin{array}{l}\text { duration; } \\
\text { dyspnoea }\end{array}$ & $\begin{array}{l}\text { duration; } \\
\text { dyspnoea; } \\
\text { fever; } \\
\text { wheezing }\end{array}$ & $\begin{array}{l}\text { appearance; } \\
\text { temperature; look at } \\
\text { respiratory rate OR } \\
\text { for chest recession }\end{array}$ & $\begin{array}{l}\text { appearance; } \\
\text { look at respiratory } \\
\text { rate or chest } \\
\text { recession; } \\
\text { temperature; } \\
\text { ascultation }\end{array}$ \\
\hline Vaginal discharge & $\begin{array}{l}\text { duration; } \\
\text { type (itch, colour etc. } \\
x 1 \text { of }\end{array}$ & $\begin{array}{l}\text { duration; } \\
\text { type: at least } 2 \\
\text { characteristics }\end{array}$ & $\begin{array}{l}\text { abdominal } \\
\text { examination }\end{array}$ & $\begin{array}{l}\text { speculum exam OR } \\
\text { referral }\end{array}$ \\
\hline
\end{tabular}


norms and is potentially dangerous (such as giving a child chlorpromazine). In all, 451 consultations by 50 health workers at 45 facilities were observed and categorized.

At each consultation, the observer also measured provider interpersonal conduct by matching behaviour against 4 graded basic indicators: whether they made the patient comfortable; whether they allowed the patient or guardian to explain their problem or complaint; whether the clinician explained the diagnosis and treatment to the patient or guardian; and whether they ended the consultation politely. Each of these behaviours were graded, and combined to give a score out of 100 . The Assessment Panel described above examined the scoring system and decided that consultations scoring less than 70 were inadequate.?

User views were compared on the observed patients by interview shortly after the consultation. To ensure respondents were comparable, only services where users had a choice between government and voluntary facilities were included. There were more government facilities than facilities run by voluntary agencies. Therefore, all government facilities 5 kilometres or more from any voluntary agency were excluded. This left a facility sample of 18 government and 15 voluntary facilities. The interviewers explained they were not employed by the health service, but wanted to find out the user's opinion of the care received. In all, 316 patients were interviewed.

\section{Results}

A greater proportion of outpatient staff were medical or paramedical at voluntary facilities $(12 / 16)$ compared with government $(11 / 33)$. Voluntary facilities tended to see fewer patients (average daily volume of 20 compared with 31 ; $95 \% \mathrm{CI}$ of the difference $0.3,21)$. Drug availability was similar, but the infrastructure of voluntary services was better $(13 / 15$ voluntary facilities had water, toilets and a leak-free roof, compared with $3 / 28$ in government facilities; $14 / 15$ voluntary facilities had a thermometer, stethoscope and sphygmomanometer, compared with $17 / 28$ at government centres).

Table 2 shows that voluntary agencies had a higher proportion of acceptable clinical performance. However, the proportion of consultations with serious errors or potentially dangerous treatments was similar. Excluding consultations conducted by doctors did not alter these findings. Voluntary agency staff prescribed more drugs on average $(2.6$ drugs per prescription compared with 1.7 ; difference $=0.9,95 \%$ confidence interval 0.7 to 1.0 ). Voluntary providers had a higher proportion of consultations lasting three or more minutes, and of consultations where interpersonal conduct was classified as adequate.

A comparison of voluntary agency and government users (Table 3 ) shows that users of voluntary services were more likely to have completed

Table 2. Quality compared between consultations at government (consultations $=295$ ) and voluntary agency (consultations $=156$ ) providers. Values are percentages of consultations reaching explicit standards of care

\begin{tabular}{|c|c|c|c|}
\hline & Government & Voluntary & $\begin{array}{c}\text { Difference (95\% confidence } \\
\text { interval) }\end{array}$ \\
\hline Acceptable clinical performance & 24 & 39 & $+15(+6$ to +24$)$ \\
\hline $\begin{array}{l}\text { Potentially serious diagnostic/prescribing } \\
\text { error* }\end{array}$ & 36 & 38 & $+2(-7$ to +11$)$ \\
\hline Consultations $>3$ minutes & 59 & 78 & $+19(+10$ to +27$)$ \\
\hline Adequate interpersonal conduct & 51 & 73 & $+22(+13$ to +30$)$ \\
\hline
\end{tabular}

\footnotetext{
* potentially serious diagnostic error, or a treatment given that is contrary to established norms with potentially serious adverse effects.
} 
Table 3. Comparison of users of government (respondents $=175$ ) and voluntary agency (respondents $=141$ ) facilities. Values are percentages of respondents.

\begin{tabular}{|c|c|c|c|c|c|}
\hline & & $\begin{array}{l}\text { Government } \\
\text { (\%) }\end{array}$ & $\begin{array}{l}\text { Voluntary } \\
(\%)\end{array}$ & Difference & $\begin{array}{l}\text { Difference }(95 \% \\
\text { confidence interval }\end{array}$ \\
\hline Education & not completed primary education & $\$ 1$ & 25 & -26 & $(-16$ to -36$)$ \\
\hline Employment & $\begin{array}{l}\text { peasant farmers or public sector } \\
\text { employees }\end{array}$ & 38 & 22 & -16 & $(-6$ to -26$)$ \\
\hline $\begin{array}{l}\text { Reasons for } \\
\text { use }\end{array}$ & $\begin{array}{l}\text { close by } \\
\text { good treatment } \\
\text { polite service } \\
\text { other }\end{array}$ & $\begin{array}{r}87 \\
12 \\
1 \\
12\end{array}$ & $\begin{array}{r}26 \\
81 \\
6 \\
12\end{array}$ & $\begin{array}{r}-60 \\
+70 \\
+5 \\
0\end{array}$ & $\begin{array}{r}(-52 \text { to }-69) \\
(+77 \text { to }+61) \\
(0 \text { to }+9)\end{array}$ \\
\hline $\begin{array}{l}\text { Consultation } \\
\text { received }\end{array}$ & reported as good & 56 & 80 & +24 & $(+14$ to +34$)$ \\
\hline $\begin{array}{l}\text { Aspects that } \\
\text { should be } \\
\text { improved }\end{array}$ & $\begin{array}{l}\text { drug supply } \\
\text { building } \\
\text { staff attitudes } \\
\text { provide extra services }\end{array}$ & $\begin{array}{l}41 \\
29 \\
17 \\
12\end{array}$ & $\begin{array}{l}11 \\
25 \\
27 \\
37\end{array}$ & $\begin{array}{r}-30 \\
-4 \\
+10 \\
+24\end{array}$ & $\begin{array}{r}(-21 \text { to }-39) \\
(-14 \text { to }+5) \\
(+1 \text { to }+19) \\
(+15 \text { to }+34)\end{array}$ \\
\hline
\end{tabular}

primary education and less likely to come from low income groups. Voluntary facility users came because of good treatment; and they were more satisfied with the care received. Nevertheless, this group wanted improvements in staff attitudes, despite the higher interpersonal scores at these facilities, and additional services. These findings contrast with the government users, where the majority of users came because the facilities were close by, and a larger proportion wanted improvements in the drug supply.

\section{Discussion}

Potential biases arise in this study because the clinical recorders and Assessment Panel were not blind to the facility type. However, the use of explicit criteria ensured this possible bias was minimized. In addition, the small number of voluntary agencies, and their heterogeneous nature, means that the generalization of quality differences between these provider types in other cities or countries cannot be made without additional data. Nevertheless, this case study in one city highlights some issues for policy makers concerned with the voluntary sector providing health services in Tanzania and other low income countries.
First, health ministries need to consider carefully how they define and classify voluntary status. In this study, half of the providers officially classified as voluntary were for-profit private practitioners, benefitting from charity tax concessions. ${ }^{7}$ Second, the study suggested better clinical performance and interpersonal conduct at voluntary agencies when compared with government; and user satisfaction was higher at voluntary providers overall. Third, despite better performance, there remained a large proportion of consultations at voluntary facilities where care was potentially dangerous or outside established clinical practice. This finding needs further examination and detailed work examining user characteristics and case mix which might be different at the different types of facilities. However, it highlights the need for governments engaged in encouraging voluntary sector expansion to introduce effective monitoring and regulatory mechanisms that ensure safe practice, ${ }^{8}$ as well as improving care in government services. Indeed, the Ministry of Health in Tanzania is now actively pursuing this. ${ }^{9}$ Finally, government and voluntary providers were seeing users from different economic groups. This is probably because voluntary services charge, whilst government services do not. Introducing user charges at government facilities during 1993 
could impair access of poorer groups to basic health care, and must be carefully monitored.

\section{References}

1 World Bank. Investing in Health: The World Development Report. Washington: The World Bank, 1993.

${ }^{2}$ Gilson L. Value for money? The efficiency of primary health care units in Tanzania. London: University of London, PhD thesis, 1992.

3 Abel-Smith B, Rawal P. Can the poor afford "free" health services? A case study from Tanzania. Health Policy and Planning 1992; 7: 329-41.

4 Mburu F. Availability and determinants of access to health services in Dar-es-Salaam, Tanzania: a survey of user/provider patterns. Dar-es-Salaam: City Council, 1990.

SGarner P, Thomason J, Donaldson D. Quality assessment in rural health facilities in Papua New Guinea. Health Policy and Planning 1990; 5: 49-59.

${ }^{6}$ Handbook on essential drugs: a guide for rural medical aides and medical assistants. Dar-es-Salaam: Ministry of Health and Social Welfare and the United Nations Childrens Fund, 1987.

${ }^{7}$ Kanji N, Kilima P, Munishi G. Quality of primary curative care in Dar-es-Salaam. Dar-es-Salaam: Urban Health Project Research Report, 1992.

${ }^{8}$ Gilson L, Sen P D, Mohammed S, Mujinja P. The potential of health sector non-governmental organizations: policy options. Health Policy and Planning 1994; 9(1): 14-24.

${ }^{9}$ Ministry of Health and Dar-es-Salaam City Council. Quality of care in Dar-es-Salaam: policy workshop report. Dar-es-Salaam: City Council, 1993 (mimeo).

\section{Acknowledgements}

Thanks to health staff in Dar-es-Salaam, research advisers $T$ Harpham, $M$ Tanner and $M$ Wolff; field staff Zuhura
Majapa, Frederick Mlekwa, Frank Matemu and Audaz Mutagwawho. Field work was supported by the Dar-esSalaam Urban Health Project, financed by the Tanzanian Government and the Swiss Development Corporation. The Urban Health Programme, London, is supported by a grant from the Overseas Development Administration (UK).

\section{Biographies}

Najmi Kanji, MSc, is a health development specialist working with the Aga Khan in Dar es Salaam. He has extensive experience in implementing national essential drugs programmes and evaluating health interventions. He has been a prominent voice in highlighting the negative effects of structural adjustment programmes on the poor.

Peter Kilima is a senior public health specialist and epidemiologist. He is currently Deputy City Medical Officer of Dar es Salaam, and manager of the Dar es Salaam Urban Health Project. His research includes schistosomiasis, chronic diseases and disability. He is secretary of the East African Public Health Association.

Nicolaus Lorenz is a senior public health specialist with the Swiss Tropical Institute. He has worked for 7 years in Burkina Faso, and his current research concerns urban health and the management of health systems. He is president of the Medicus Mundi Switzerland, an organization that coordinates Swiss non-government organizations working in medical development.

Paul Garner works at the Liverpool School of Tropical Medicine in the International Health Division. He is interested in planning and managing health services using reliahle evidence that estimates the effectiveness of care and that assesses the efficiency of the various ways it is delivered.

Correspondence: Dr Paul Garner, International Health Division, Liverpool School of Tropical Medicine, Pembroke Place, Liverpool, L3 SQA, UK. 